\title{
Activity Based Costing knowledge: empirical study on small and medium- size enterprises
}

Conhecimento de Custeio Baseado em Atividades: estudo empírico sobre empresas de pequeno e médio porte

\section{Maria João Cardoso Vieira Machado}

Doutora em Contabilidade pelo Instituto Universitário de Lisboa (ISCTE-IUL)

Professora do Mestrado em Contabilidade do ISCTE-IUL

Endereço: Avenida das Forças Armadas

CEP: 1649-026 - Lisboa - Portugal

E-mail: maria.joao.machado@iscte.pt

Telefone: (00) (351) 21790-3939

Artigo recebido em 26/01/2012. Revisado por pares em 03/06/2012. Reformulado em 11/10/2012. Recomendado para publicação em 31/10/2012 por Sandra Rolim Ensslin (Editora Científica). Publicado em 14/12/2012. 


\begin{abstract}
The objective of this paper is to analyze the percentage rate of use and knowledge of activitybased costing (ABC) in small and medium-sized Portuguese enterprises and at the same time searching for the existence of any factors that might explain why this method is not is used among most companies. The collected data allow us to conclude that none of these enterprises uses the $\mathrm{ABC}$ and that the majority of respondents did not have any knowledge on the subject. Hierarchical level, age and academic qualifications are the reasons why the knowledge of the $\mathrm{ABC}$ is associated to the individual characteristics of people responsible for management accounting.
\end{abstract}

Keywords: Activity-based costing. SMEs (small and medium sized enterprises). Portugal.

\title{
Resumo
}

O objetivo deste artigo é analisar a taxa percentual de uso e o conhecimento do custeio baseado em atividades ( $\mathrm{ABC}$ ) nas empresas de pequeno e médio porte portuguesas e, ao mesmo tempo pesquisar a existência de quaisquer fatores que poderiam explicar a razão pela qual este método não é usado entre a maioria das empresas. Os dados coletados permitem concluir que nenhuma dessas empresas utiliza o $\mathrm{ABC}$ e que a maioria dos entrevistados não têm conhecimento algum sobre o assunto. Nível hierárquico, idade e qualificação acadêmica são as razões pelas quais o conhecimento do $\mathrm{ABC}$ está associado às características individuais das pessoas responsáveis pela contabilidade gerencial.

Palavras-chave: Custeio baseado em atividades. PME. Portugal

\section{Introduction}

The objective of this paper is to contribute to an increase in the overall awareness of Activity Based Costing (ABC) among the Portuguese industrial small and medium sized enterprises (SME's). Specifically, this paper aims at analyzing both the use of said knowledge and the rate at which this knowledge is spread among the Portuguese SME's; while at the same time identifying the reasons why $\mathrm{ABC}$ is known in some companies as opposed to others.

Investigators today are still concerned whether companies are using the most adequate accounting method, more specifically the Activity Based Costing (KAPLAN, 2006; HOPPER; MAJOR, 2007; RIVERO; EMBLEMSVAG, 2007; BHIMANI et al., 2007; AGNDAL; NILSSON, 2007; BHIMANI et al., 2007; MAIGA; JACOBS, 2008; ENGLUND; GERDIN, 2008; DRAKE; HAKA, 2008; BANKER et al., 2008; KALLUNKI; SILVOLA, 2008; HOOZÉE; BRUGGEMAN, 2010; NASSAR et al., 2011; PIKE et al., 2011; STOUT; PROPRI, 2011; SCHOUTE, 2011). However the empirical study by Dearman and Shields (2001) concluded that even without using any methods which are considered theoretically accurate we can still achieve correct management 
decisions as long as the standing managers possess some knowledge of Activity Based Costing. This knowledge allows them to recognize that some of the information provided by methods which use information based on volume cost sharing may be warped (DEARMAN; SHIELDS, 2001). Thus, it is not only important to look at the rate of the use of $\mathrm{ABC}$ but also at the percentage of top managerial accounting department heads that possess any knowledge whatsoever on this process. However very few studies that analyze the management accounting practices of SME's, which justify the need for new research in this type of enterprises (HOPPER et al., 1999).

This study focuses on Portugal due to high prevalence of SME's in Portuguese market. A study realized in Portugal (IAPMEI, 2008) refers that $99.6 \%$ of the national companies are either small or medium sized which confers a huge relevance to a study of this sort in order to better portray the country's situation. The practices of management accounting organizations are poorly disclosed in Portugal, due to the optional nature of this type of accounting, which justifies the empirical studies in this country as a contribution to the contingency theory, in that it recognizes that cultural differences between countries are a factor of differentiation of management accounting methods used (YANG et al., 2006; MACARTHUR, 2006). The current funding problems of the Mediterranean European countries require a greater capacity for management of enterprises, which also gives importance to the study of management accounting practices of Portuguese companies. There are over 297.000 SME's in Portugal as of 2005 (IAPMEI, 2008). This forces me to impose further restrictions on my sample. I have narrowed down my study to benchmark industrial SME's. The reason why I narrowed it down to industrial companies is that they belong to a sector which is historically known for using managerial accounting systems. The reasons why I am using benchmark SME's is justified by the fact that they already constitute a previous selection that was made with similar goals as this project seeing as how the said selection already accounted for both the economic, financial and the managerial well fare of these companies (IAPMEI, 2002). My universe includes 163 consecutive benchmark industrial SME's in the current century. The data gathering was done through several interviews to the departments' heads of managerial accounting, given these are perceived to be the ones who possess the most knowledge regarding the topic at hand. I realized 58 separate interviews of industrial enterprises spread over eleven different Portuguese districts, which implies a 36\% response rate. I also went through the no-reply requests in order to conclude that there was no statistical difference between the companies that performed the interview and the ones that didn't.

In order to present a proper clarification of the subject of this study and presentation of the final data, this paper is organized in the following manner: chapter one with introduction, chapter two with theoretical framework, chapter three with research methodology, chapter four with presentation and discussion of results, chapter five with conclusion.

\section{Theoretical Framework}

Activity Based Costing was first developed in the mid 80's when a new analysis method based on the activities of a company was developed. Two different organizations significantly contributed to the development of the ABC process: Harvard Business School, 
through two of its researchers, Robert Kaplan and Robin Cooper, as well as an R\&D organization called "Computer-Aided Manufacturing, International" which was funded by both manufacturing companies and government agencies (JONES; DUGDALE, 2002). Most researchers nowadays believe that Activity Based Costing is the best way to determine the product cost. (COOPER, 1988; SWENSON, 1995; JOHNSON, 1988; KENNEDY; AFFLECK-GRAVES, 2001; DRAKE; HAKA, 2008; MAIGA; JACOBS, 2008; PIKE et al., 2011; STOUT; PROPRI, 2011). This opinion is due to the method how costs that are not directly related to the volume of production, but instead are related to other factors such as the number of production orders or even the number of products made, are accounted for (AGNDAL; NILSSON, 2007; RIVERO; EMBLEMSVAG, 2007; MACHADO, 2009). The other methods of accounting allocate indirect costs through various cost bases depending on production volume, which in turn may not clearly reflect the true organizational cost required by the actual products (SWENSON, 1995; QUEIROZ et al., 2004; CAIADO; AMARO, 2006; MACHADO, 2009). The allocation of indirect costs across multiple bases depending on volume orders will generate an overvaluation of the end product cost when we are dealing with high volume orders while giving us an undervaluation of each product cost whenever we deal with low volume orders (JOHNSON, 1988). The information that results from using these bases of cost allocation can lead managers to misdirect their resources towards their products with less production volume (JOHNSON, 1988, BANKER et al., 2008; MACHADO, 2009). Analyzing a sample of forty seven companies in the United Kingdom, Kennedy and Affleck-Graves (2001) concluded that using ABC a more accurate evaluation of a company's managerial accounting can be achieved through both the use of managerial accounting and financial markets ratios. These authors argue that the use of $\mathrm{ABC}$ in everyday activities of a company will allow for a better distribution of the indirect costs throughout the product lines by identifying and understanding what drives the cost of each activity.

Regardless of this clear theoretical supremacy of the ABC over other methods there are still multiple papers that report low rates of usage of this method in several countries (ENGLUND; GERDIN, 2008; BHIMANI et al., 2007). In most cases, countries report a usage rate of the ABC method equal to or bellow 28\% namely in the U.K. (DRURY; TAYLES, 1994; INNES; MITCHELL, 1995; INNES et al., 2000), New Zealand (COTTON; JACKMAN, 2002), Japan (HOPPER et al., 1999), India (JOSHI, 2001), Ireland (CLARKE; O'DEA, 1994; CLARKE et al., 1999), Spain (BLAKE et al., 2000), Singapore (GHOSH, CHAN, 1997), in Malaysia (CHUN et al., 1996), Estonia (HALDMA; LÄÄTS, 2002), and Finland (LUKKA; GRANLUND, 1996; KALLUNKI; SILVOLA, 2008).

Dearman and Shields (2001) defend that, regardless of whether a company uses the $\mathrm{ABC}$ method or not, the mere fact that the people responsible for managerial accounting have some knowledge of it is advantageous to the company. These authors performed a study based on forty two managers through which they concluded that even while using inadequate costing methods, managers can still achieve the correct managerial accounting decision, as long as they have some knowledge of the ABC method. Dearman and Shields (2001) analyzed the amount of knowledge that these managers possessed regarding the behavior of costs and their role in the decision making process when faced with concrete problems of product pricing and other management accounting aspects. This study allows us to conclude that when companies use volume based costing allocation, the way that managers analyze the costs during the decision making process depends on the amount of knowledge they possess regarding the behavior of costs. When managers have knowledge regarding the ABC method 
they begin to understand that the information reported through the use of volume based costing is distorted. They then use their knowledge of activity based costing to evaluate the information that is supplied to them through their formal accounting system. The conclusions that these authors derived lead us to believe that it is not only important to study the rate of use of the ABC knowledge in the Portuguese companies but also the general awareness of this method among the top managers of said companies (NASSAR et al., 2011).

However the literature I reviewed suggests, although without any empirical evidence, that awareness of $\mathrm{ABC}$ can be associated to the individual characteristics of the person responsible for managerial accounting. Most authors agree that it is important to identify the factors responsible for spreading the knowledge of the ABC method, namely Shields (1998), Clarke et al. (1999) and Cohen et al. (2005). These authors analyzed characteristics such as age and academic training of the people responsible for accounting. The study regarding the relationship between the individual subject and the accounting practices is further developed by Morgan and Willmott (1993). These authors believe that it is necessary to pay greater attention to the effect of individual characteristics in their accounting practice, namely their gender. Morgan and Willmott (1993) consider that the gender gap has been ignored for far to long by researchers worldwide and they believe that it is necessary further research into this aspect namely in order to find out if an increase in the number of female people responsible for accounting would pose a significant change to the accounting practice. The training that each responsible for managerial accounting has is one of the factors that Shields (1998) and Clarke et al. (1999) consider that affect each company's accounting practices. Clarke et al. (1999) concluded that the main barrier to change in Irish companies' accounting practices were the people responsible for managerial accounting themselves due to their lack of managerial training. This factor was also analyzed using Spanish companies by Blake, Wraith, Amat (2000) where they found a wide variety in terms of academic education, being that the predominant level was higher education. The gender was also analyzed by Blake, Wraith, Amat (2000), where they found that there is a predominance of male interviewees $(62 \%)$. The age was suggested in the research performed by Cohen et al. (2005) although with no empirical evidence. These authors expressed their surprise about the high percentage of people responsible for managerial accounting who are not aware of $\mathrm{ABC}$, which in turn led them to investigate some factors that might explain this. One of the factors they found is that the people responsible for managerial accounting also represent the people with the highest seniority in the companies which according to some researchers might suggest a higher age range with no up to date knowledge.

\section{Research Methodology}

Various authors, namely Chua (1986), argue that the research method is conditioned by three sequential factors. The first refers to the predisposition that the researcher assumes regarding the nature of the reality of the phenomenon which in turn characterizes his/her ontological position. The second is the way that the researcher assumes he/she can acquire the necessary knowledge regarding the issue at hand, which will in turn characterize his/her epistemological position. The third is the methodology that the researcher considers to be more adequate in order to gather valid information regarding the desired phenomenon. The way through which one acquires knowledge regarding a specific phenomenon is conditioned 
by the way a person perceives reality, meaning that a epistemological position from a researchers standpoint has to be coherent with his ontological one. The same way that ones research methodology has to be coherent with his/her epistemological standpoint. Based on these three factors various authors have classified accounting research through the identification of its biggest paradigms (BHIMANI, 2002). One of the most common classifications used to characterize accounting research paradigms is Burrell's and Morgan's (BELKAOUI, 2000) which is based in two separate criteria. The first one defines the position of the researcher regarding the nature of social sciences, where he must place himself between two opposite extremes, objectivity and subjectivity. The second criterion translates the perspective that the researcher has of society, which can go from radical changes to regulation. The crossing of these two criteria will spawn four different research paradigms (BELKAOUI, 2000): Functionality, which is characterized by having an objective view of reality and its constant search for social stability in its pursuit of maintaining order; Interpretive which is based on the same social equilibrium however it shows us a more subjective view of reality; Radical humanism is characterized for its subjective view of reality while at the same time assuming that exist social transformations; and finally, Radical structuralism, which also bases its view of society as humanism does but it distinguishes itself through a more objective perspective of reality. In the empirical managerial accounting studies reviewed I did not find these four paradigms but only three. Functionality, also known as positivism, is used by various researchers, namely Watts and Zimmerman (1990), Chambers (1993) and Zimmerman (2001). Interpretive investigation is used by Scapens (1990), Humphrey and Scapens (1996), Covaleski and Dirsmith (1988) and Burns and Scapens (2000), among others. Both human and structuralized radicalism are usually grouped into a single category, critical investigation (COVALESKI; DIRSMITH, 1996; BHIMANI, 2002; BAXTER; CHUA, 2003). At the end of the sixty's decade positivism started to be used in accounting research (CHAMBERS, 1993). This approach has a subjacent conception which is based on reality (BHIMANI, 2002; CHUA, 1986) and the existence of a logic behind the rationality of decision making, which would be solely based on accounting information (BHIMANI, 2002; COVALESKI; DIRSMITH, 1996), thus ignoring the problem of organizational conflict. This conception leads to a view of reality as something that is external to the researcher which assumes that the participants in the organizations are passive and therefore do not influence their surroundings (CHUA, 1986). This paradigm distinguishes itself through the fact that the observation of the events is itself separate from the theory and can therefore be used to validate it (CHUA, 1986).

After a thorough review of the existing accounting research paradigms I decided that the use of the positivism research method might be the best solution considering that the type of evidence that I plan to gather is compatible with an objective view of reality. Furthermore seeing as how this method considers the researcher as something external to reality then a more a rational decision can be reached based solely on the accounting information gathered, characteristics clearly associated to this research paradigm (CHUA, 1986). The purpose of this research are not compatible with the subjective view of reality associated to the interpretive research method neither with the need to recognize and analyze the sources of existing conflict existent within accounting which is associated with critical investigation. Based on the chosen research paradigm I was able to formulate the following research questions:

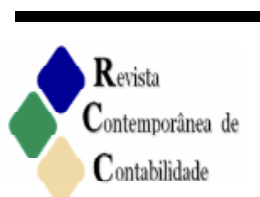


Research Question A - Do Portuguese industrial SME's use activity based costing?

Research Question B - Are people responsible for managerial accounting aware of the existence of ABC?

Research Question C - Is there a direct link between the general awareness of ABC and other explanatory determining factors?

Pertaining the method for data gathering, our research questions narrowed our options down to two, inquiries or interviews, seeing as how the data that I am trying to collect is not publicly disclosed by companies. One of the main advantages to the use of interviews as a data gathering method is the fact that in Portugal the data that I am trying to gather is not yet standardized which in turn would generate multiple denominations for the same information. The use of interviews allows for the explanation of each individual concept to the interviewee which generates a greater reliability on data collected (BELL, 2005). The semi-structured interviews are particularly useful to both gather information about the issues of which there is no certainty that all the interviewees grasp the concepts that the researcher is trying to evaluate (ABERNETHY et al., 1999). Inquiries are a more adequate method of data gathering when considering standardized concepts which are shared among all of the intervenient, which is not the case in this particular research paper (ABERNETHY et al., 1999). The fact that the inquired people have no opportunity to clarify any doubts regarding the questions might influence the results of the investigation itself. Taking into consideration the selected research questions I opted for the use of interviews which would allow me to gather the most diversified data as possible regarding the issues at hand. The reason why I chose to use interviews as my research method was so that I could gather the most reliable data seeing as how even the most basic managerial accounting principles might not be used the same way by all of the Portuguese companies. I decided to use semi-structured interviews in which I wouldn't use a questionnaire but instead a set of topics which the interview has to follow (BELL, 2005). The interviews were directed solely towards the person responsible for managerial accounting seeing as how these people are the ones who are supposed to have the required data that $I$ intend to gather and, given the size of the companies, a global view of its reality.

My universe includes 163 consecutive benchmark industrial SME's in the current century. After performing three sets of scheduling attempts I managed to schedule meetings with fifty eight companies. The interviews were performed with the people responsible for the managerial accounting. I analyzed companies from eleven out of the fourteen districts, which comprised my original goal. Given the fifty eight companies that accepted to participate in this investigation I got a $36 \%$ response rate which is comparable to papers which I analyzed during my literary review, namely Drury and Tayles (1994) which obtained a response rate of $35 \%$, Haldma and Lääts (2002) who have a response rate of 34\%, Innes and Mitchell (1995), Innes et al. 2000), Joshi (2001), who got 25\%, $23 \%$ and $24 \%$ response rate, accordingly. However, the existence of non-participants might skew the results, namely if the companies that did not accept to participate have a homogeny of characteristics and are not spread out, therefore defining themselves as a new category of companies (YOUNG et al., 2005). These researchers believe that this problem is more relevant due to the way how companies that participate are different from the ones that don't, rather then the response rate itself. During this research there were no traces of any results being skewed due to the companies that did not participate by analyzing three different factors. First, the geographical cover of the 
Portuguese territory, seeing as how the participating companies covered $79 \%$ of the available districts. Furthermore there was only one non participating company in each of the remaining districts which suggests that I have a good geographical spread and therefore the results are not skewed. After that I analyzed the participating companies industry sector. I was able to verify that there was a wide enough representation of the existing sectors both in the sample companies as well as in the non participating companies and therefore concluded that this also does not skew our results. Lastly I looked at the size of the companies through which, according to Young et al. (2005), one can measure the number of workers in each company. I compared the size of the participating and the non participating companies using an average number of workers. The t-student test has a score of 1.165 with 161 degrees of freedom and a p-value of 0.246 which indicates that there are no significant differences between the average size of these two groups. This research allowed me to concluded that the results of this study, even though they are not true for all of the Portuguese industrial SME's, can accurately show the reality of a subset of these companies, in particular the ones classified as benchmark in both 2000 and 2001. Abernethy et al. (1999) concluded that regardless of the research method used, to generalize something based solely on a single research paper is necessarily limited and therefore untrustworthy. These authors believe that generalizing in managerial accounting has to be achieved through a series of consecutive studies with new samples, different places and different time periods.

\section{Presentation and Discussion of Results}

Pertaining research question $\mathrm{A}$ the gathered evidence allows me to conclude that no company uses the $\mathrm{ABC}$ method which calls for special attention when looking at the awareness regarding this method.

For analyzing Research Question B I created a variable which reflects the knowledge of $\mathrm{ABC}$, called "ABC knowledge". The results I obtained allow me to conclude that the majority (59\%) of the people responsible for managerial accounting is not aware of $\mathrm{ABC}$. The remaining $41 \%$ are aware of the method but don't have a homogeneous view of its use: only $5 \%$ showed an interest in the method and any interest in eventually using it; the remaining $36 \%$ didn't show any interest in its eventual use in their respective companies. The actual knowledge of the $\mathrm{ABC}$ method comes from different sources: managers' academic training, graduate studies or even just reading articles regarding the subject.

In order to be able to study the existing relationship between the awareness of $A B C$ and the individual characteristics of the interviewees I was required to cross the variable "ABC knowledge" with other variables which reflected the characteristics, such as position in the company, academic qualifications, gender and age, of the interviewees. I found three categories responsible for managerial accounting: in all the companies where there is a Chief Financial Officer (CFO), this person is responsible for managerial accounting (52\%); in $40 \%$ of the cases the responsibility of managerial accounting is awarded to a Board Member; in the remaining $8 \%$ of the sample companies the person responsible for managerial accounting is the Official Accounting Technician (OAT). Due to their light weight, the latter category was added in the first, thus creating a variable called "hierarchical level" with just two categories. The first is comprised of the Chief Financial Officers and the Official Accounting Technicians (CFO or OAT), seeing as how these two categories have the most comparable knowledge of

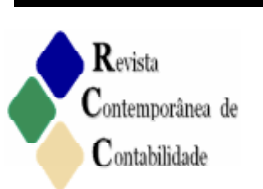

ISSN 2175-8069, UFSC, Florianópolis, v.9, n.18, p.167-186, jul./dez., 2012 
$\mathrm{ABC}$. The second category is comprised of the companies where the people responsible for managerial accounting are the board members themselves. In order to analyze the relationship between the variables "ABC knowledge" and "hierarchical level" it was necessary to perform a cross match of the answers as it is shown in Table 1.

Table 1 - Variables "ABC knowledge" and "hierarchical level"

\begin{tabular}{l|l|c|c|c}
\hline \multirow{2}{*}{\multicolumn{2}{c|}{}} & \multicolumn{2}{|c}{ Hierarchical level } & \multirow{2}{*}{ Total } \\
\cline { 3 - 5 } \multicolumn{2}{c|}{} & CFO or OAT & Board Member & \\
\hline \hline \multirow{2}{*}{ ABC knowledge } & Does not know & 17 & 17 & 34 \\
\cline { 2 - 5 } & Knows & 18 & 6 & 24 \\
\hline \hline \multicolumn{2}{l|}{ Total } & 35 & 23 & 58 \\
\hline
\end{tabular}

Source: Elaborated for the authors.

Figure 1 shows some evidence of a difference between the categories from the answer from the variable "ABC knowledge" and the hierarchical level suggesting that there might indeed exist a relationship between the behavior of these two variables. Knowledge regarding $\mathrm{ABC}$ is proportionally higher among CFO's or OAT's then Board Members. Most CFO's and OAT's know ABC (51\%) while only $26 \%$ of Board Members who are responsible for managerial accounting have any knowledge regarding this method. In order to verify any existing statistically relevant relation between these two variables I resorted to the Pearson Chi-Square test. The result was a value of 3.675 with one degree of freedom and a p-value of 0.055 which allows me to reject the null hypothesis of independence of these variables, for an error of $10 \%$, and accept that there is an association between the hierarchical level and ABC knowledge.

Figure 1 - Variables "ABC knowledge" and "hierarchical level"

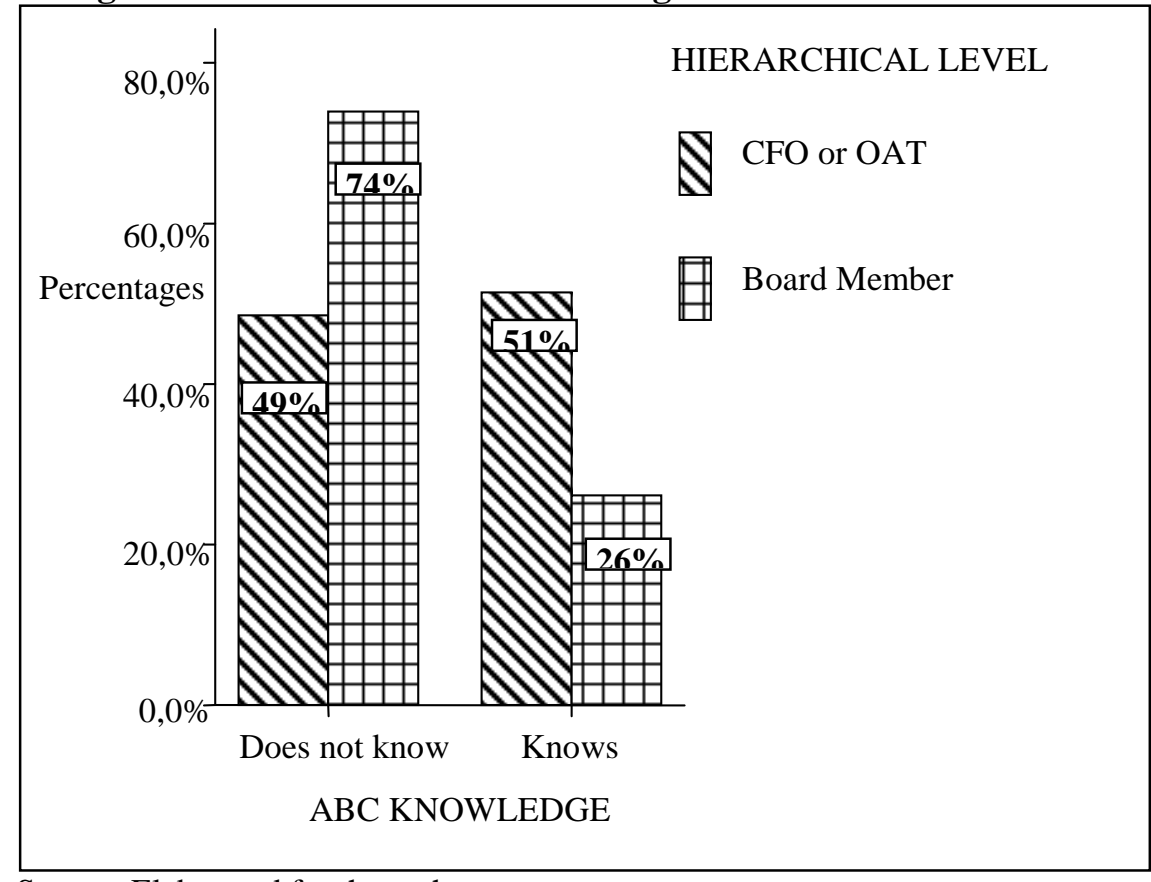

Source: Elaborated for the authors. 
During the course of this study I also found a wide variety of training level of the people responsible for managerial accounting. In $21 \%$ of the companies the person responsible for managerial accounting didn't possess any type of higher education. The majority $(71 \%)$ of those responsible do in fact possess academic training at a college level. The most frequent answer focused on those majored in Management (36\%), followed by the ones in Accounting (16\%), Economics (12\%) and lastly Engineering (7\%). The highest level of education found was at a Master's level and it represents $8 \%$ of our sample. Due to the high dispersion, I aggregated together the categories, thus creating a variable called "academic qualifications" which narrowed it down to just three categories which are presented in Table 2. The first category includes the people without any type of higher education. The second includes the ones majored in accounting and management regardless if it is either at College or Masters level. This aggregation was based on the perception that, seeing as how this job is based in accounting courses, then both these type of Majors would be the best suited for this area of expertise. The third category was constructed as a residual and includes the remaining people with higher education in other areas of expertise.

Table 2 - Variables "ABC knowledge" and "academic qualifications"

\begin{tabular}{l|l|c|c|c|c}
\hline \multirow{2}{*}{\multicolumn{2}{c|}{}} & \multicolumn{3}{c|}{ Academic qualifications } & \multirow{2}{*}{ Total } \\
\cline { 3 - 6 } \multicolumn{2}{c|}{} & $\begin{array}{c}\text { Without } \\
\text { degree }\end{array}$ & $\begin{array}{c}\text { Graduates in } \\
\text { Accounting/ } \\
\text { Management }\end{array}$ & $\begin{array}{c}\text { Another } \\
\text { degree }\end{array}$ & \\
\hline \hline \multirow{2}{*}{ ABC knowledge } & Does not know & 12 & 16 & 6 & 34 \\
\cline { 2 - 6 } & Knows & 0 & 19 & 5 & 24 \\
\hline \hline \multicolumn{1}{l|}{ Total } & 12 & 35 & 11 & 58 \\
\hline
\end{tabular}

Source: Elaborated for the authors.

Figure 2 is a graphical representation of the association between the variables "ABC knowledge" and "academic qualifications" and it shows some differences regarding the categories of answers which suggest that some relation between the two variables does exist. The people with no higher education have no knowledge of ABC. Awareness of ABC seems to be proportionally higher with the ones with higher education in accounting or management $(54 \%)$ then with the people majored in other areas of expertise $(45 \%)$. The Pearson ChiSquare test results in a 10.949 score with 2 degrees of freedom and a p-value of 0.004 which allows me to reject the null hypothesis of independence and acknowledge the possibility that a relationship between $\mathrm{ABC}$ and the academic qualifications of the people responsible for managerial accounting does indeed exist. In order to measure the intensity of the relationship between these two variables I applied the Cramer coefficient which in this case is 0.434 with a p-value of 0.004 which allows me to confirm the rejection of the null hypothesis of independence between these two variables and to consider that there is indeed a moderate relationship between each other. 
Figure 2 - Variables "ABC knowledge" and "academic qualifications"

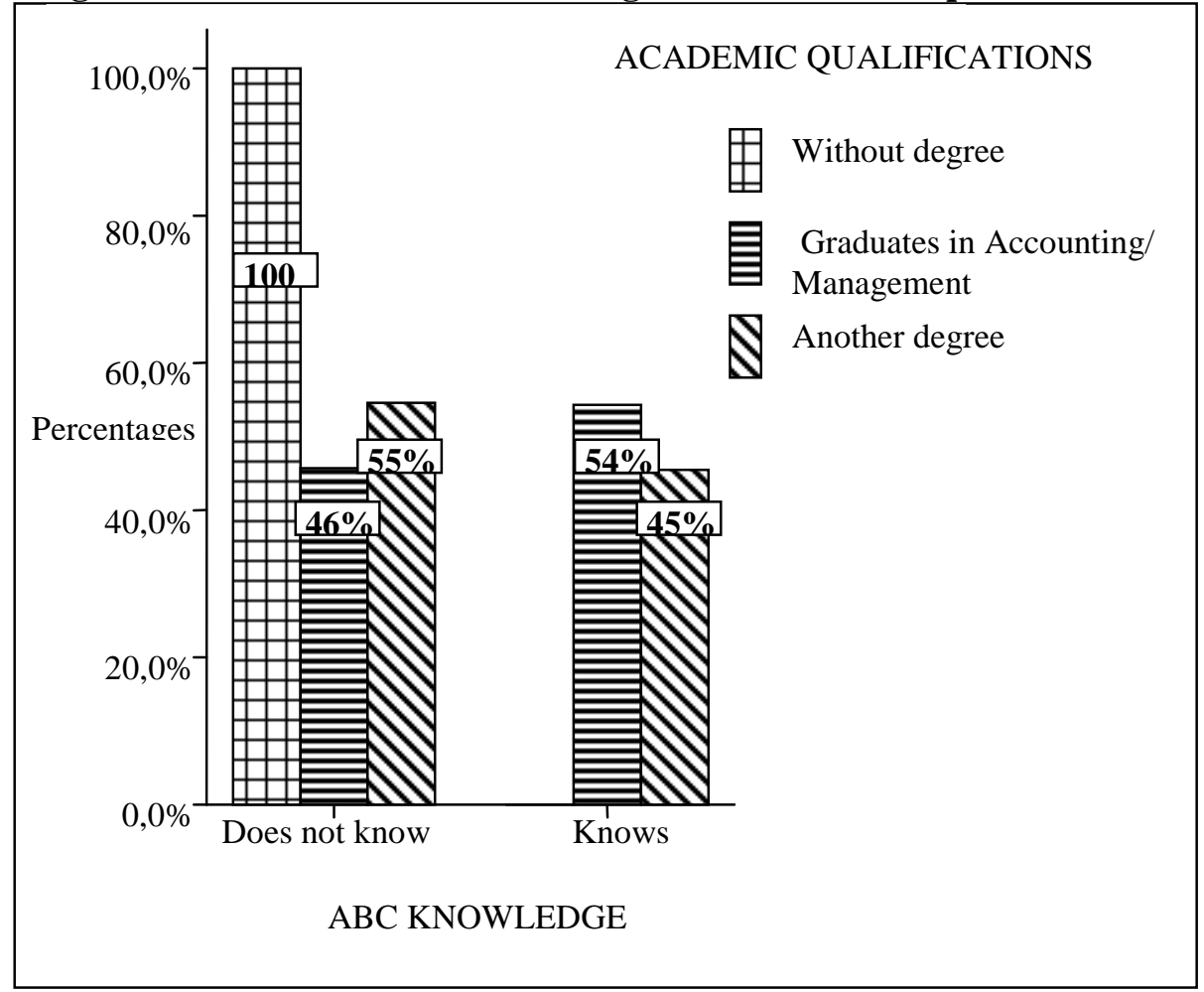

Source: Elaborated for the authors.

The variables which are yet to relate to $\mathrm{ABC}$ are gender and age of the people responsible for managerial accounting. In relation to the variable "gender", information obtained shows some identical results as the ones reported by Blake et al. (2000), as the majority of people responsible for managerial accounting are male (76\%). The results obtained from comparing the results from the variables "ABC knowledge" with "gender" are reported in Table 3 and Figure 3.

Table 3 - Variables "ABC knowledge" and "gender"

\begin{tabular}{l|l|c|c|c}
\hline \multicolumn{2}{c|}{} & \multicolumn{2}{c}{ Gender } & \multirow{2}{*}{ Total } \\
\cline { 3 - 5 } \multicolumn{2}{c|}{} & Female & Male & \\
\hline \hline \multirow{2}{*}{ ABC knowledge } & Does not know & 7 & 27 & 34 \\
\cline { 2 - 5 } & Knows & 7 & 17 & 24 \\
\hline \hline \multicolumn{2}{l|}{ Total } & 14 & 44 & 58 \\
\hline
\end{tabular}

Source: Elaborated for the authors.

These results clearly show the same type of answer range in all of the different categories in both variables, thus suggesting that there is no relation between them. The Pearson Chi-Square test confirms this information by resulting in a 0.565 score with 1 degree of freedom and a p-value of 0.452 which doesn't allow me to reject the null hypothesis of independence between awareness of $\mathrm{ABC}$ and gender. 


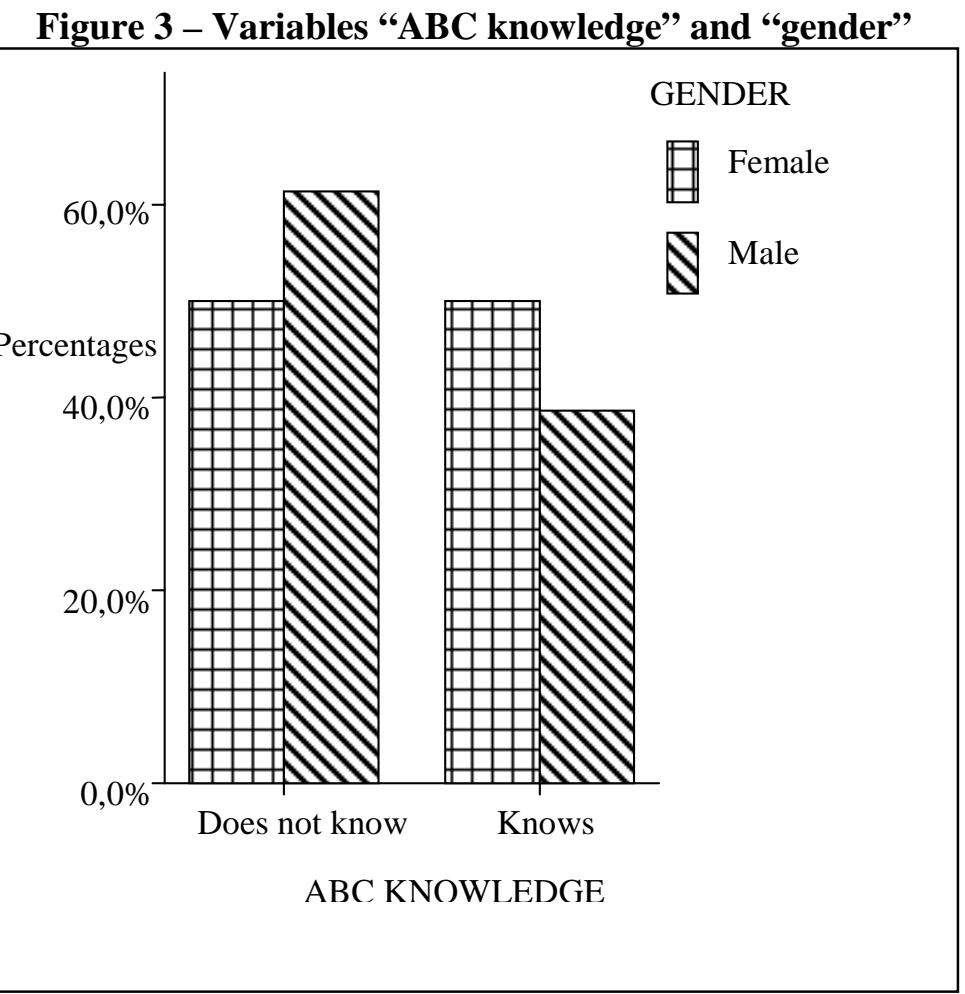

Source: Elaborated for the authors.

The variable "age" was taken into consideration during the conception of the interviews which means that it is already influencing our data. Due to some restraint when asking directly the age of the interviewees, there were three age intervals created where the interviewees themselves checked into: the first category includes the interviewees bellow the age of 40; the second age range goes from 40 to 60 years and it records the majority (53\%) of the interviewees; lastly I have the people with ages over 60 years old (16\%). In order to analyze the relation between awareness of $\mathrm{ABC}$ and the age range of our participants I crossed the variables "ABC knowledge" and "age" in Table 4.

Table 4 - Variables "ABC knowledge" and "age"

\begin{tabular}{l|l|c|c|c|c}
\hline \multirow{2}{*}{\multicolumn{2}{c|}{}} & \multicolumn{3}{c|}{ Age } & \multirow{2}{*}{ Total } \\
\cline { 3 - 6 } \multicolumn{2}{c|}{} & $\begin{array}{c}\text { Less than 40 } \\
\text { years }\end{array}$ & $\begin{array}{c}\text { Between 40 and } \\
60 \text { years }\end{array}$ & $\begin{array}{c}\text { Over } 60 \\
\text { years }\end{array}$ & \\
\hline \hline \multirow{2}{*}{ ABC knowledge } & Does not know & 5 & 22 & 7 & 34 \\
\cline { 2 - 6 } & Knows & 13 & 9 & 2 & 24 \\
\hline \hline \multicolumn{2}{l|l}{ Total } & 18 & 31 & 9 & 58 \\
\hline
\end{tabular}

Source: Elaborated for the authors.

In Figure 4 I graphically translate that information. It shows there is some concentration of answers in two categories which implies some relation between these two variables. In the age range of people below 40 years old, $72 \%$ of the interviewees are aware of $\mathrm{ABC}$. Meanwhile in the age range of people above 60 years old $78 \%$ aren't aware of this method.

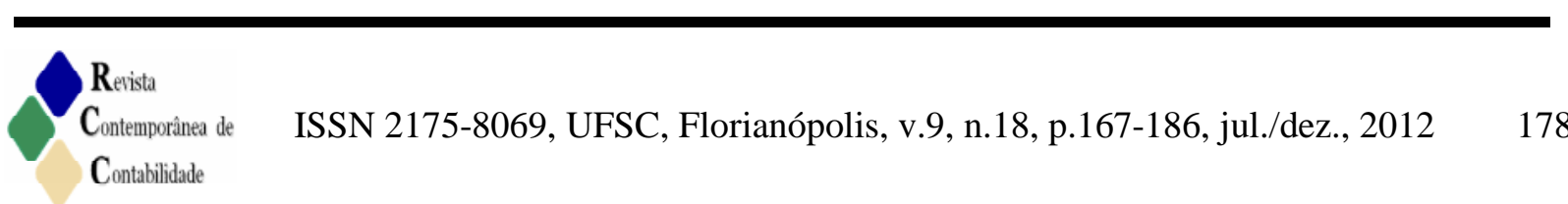


Figure 4 - Variables "ABC knowledge" and "age"

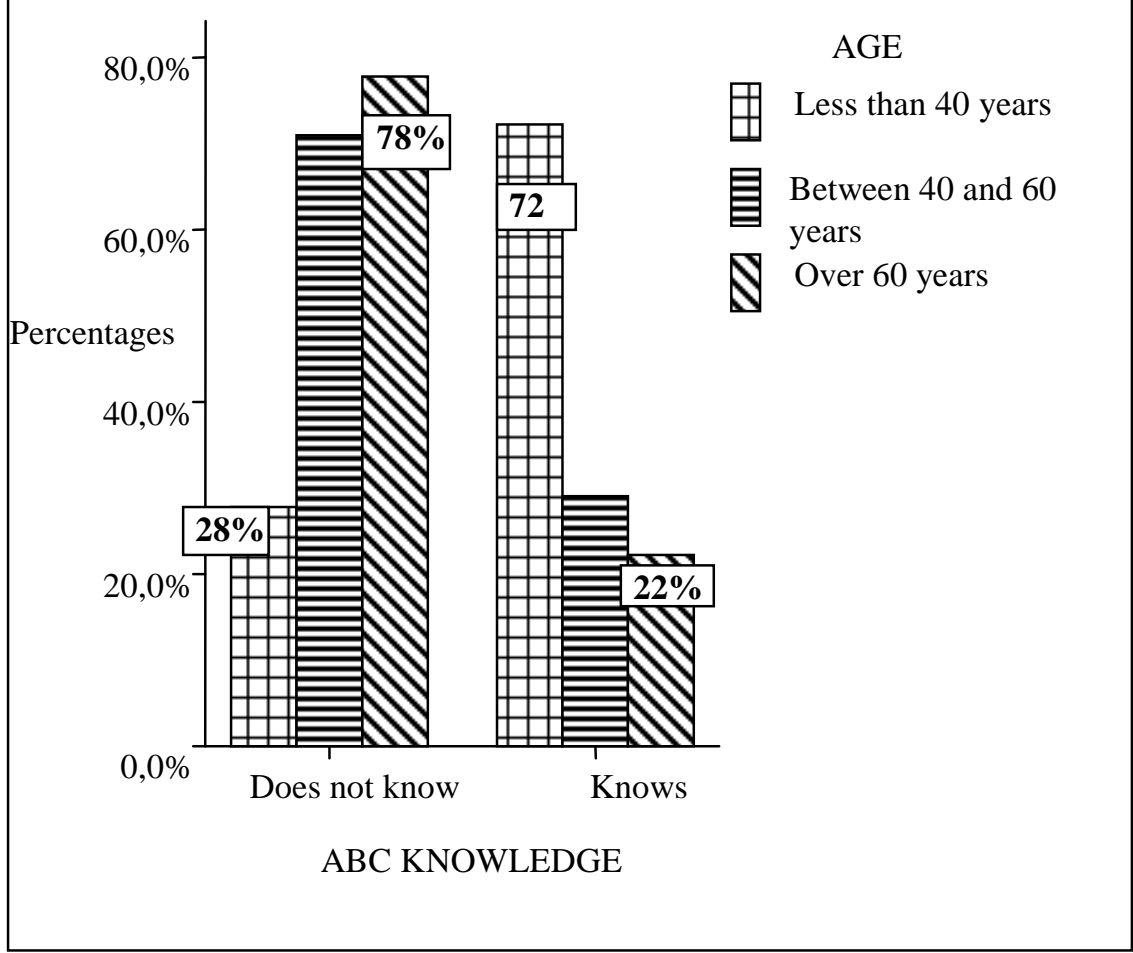

Source: Elaborated for the authors.

By applying the Pearson Chi-Square test I get a score of 10.369 with two degrees of freedom and a p-value of 0.006 which allows me to reject the null hypothesis of independence and accept the alternative hypothesis that there is a relation between being aware of $\mathrm{ABC}$ and the age of an individual. In order to measure the intensity of the relation between these two variables I calculated the Cramer coefficient which is 0.423 with a p-value of 0.006 which allows me to acknowledge the rejection of the null hypothesis of independence between these variables and consider the fact that there is at least a moderate relation between both of them.

\section{Final Remarks}

Theory shows that $\mathrm{ABC}$ has a clear supremacy over the determination of the cost of each product. However in the empirical studies that have been performed so far it continues to report a low rate of usage. The first objective of this study is to analyze the use of ABC in the Portuguese industrial SME's. The information gathered allows me to conclude that the sample companies do not use this method. The literature I reviewed suggests that even if ABC is not being used the fact that the people responsible for managerial accounting are aware of it is advantageous to their companies. It allows them to be aware that the information that is reported using volume based allocation methods is skewed towards an over-valuation of the products that are mass manufactured and that products that are produced in low numbers are under valuated. This fact makes it relevant to study the awareness of $\mathrm{ABC}$ among people responsible for managerial accounting which constitutes the second goal of this research paper. The evidence gathered allows me to conclude that most of the interviewees aren't aware of this method. However the literature I reviewed suggests, although without any 
empirical evidence, that awareness of $\mathrm{ABC}$ can be associated to the individual characteristics of the person responsible for managerial accounting. The third goal of this paper is to gather empirical evidence that confirms this claim. The data gathered shows a statistically relevant association between the awareness of $\mathrm{ABC}$ and three individual characteristics of the interviewees: age, academic qualification and hierarchical level of the individual. I was not able to find any relationship between knowledge of $\mathrm{ABC}$ and gender type. As the main limitations of this study I recognize the relative low number of participating companies and the possibility that the selected method of data gathering, interviews, may influence the answers of the interviewees. However this study contributes to the general awareness of managerial accounting for two reasons. First and foremost the results show that unlike the empirical studies reviewed, $\mathrm{ABC}$ is not used in Portugal in the SME's classified as benchmark. Secondly, the results also come to use by filling a lack of knowledge regarding the relationship between $\mathrm{ABC}$ and some of the individual characteristics of the person responsible for managerial accounting. The existence of these factors, although they were suggested by some of the reviewed literature, had not been empirically demonstrated yet. The data gathered suggests the need for future research with the purpose of detecting the reasons why companies aren't using the best available methods for product valuation, as supported by theoretical studies.

\section{References}

ABERNETHY, Margaret A.; CHUA, Wai Fong; LUCKETT, Peter F.; SELTO, Frank H. Research in managerial accounting: Learning from others' experiences. Accounting and Finance, n. 39, p. 1-27, 1999.

AGNDAL, Henrik; NILSSON, Ulf. Activity-based costing: effects of long-term buyersupplier relationships. Qualitative Research in Accounting, v. 4, n. 3, p. 222-245, 2007.

BANKER, R. D.; BARDHAN, I. R.; CHEN, T. The role of manufacturing practices in mediating the impact of activity based costing on plant performance. Accounting Organizations and Society, n. 33, p. 1-19, 2008.

BAXTER, J.; CHUA, W. F. Alternative management accounting research - whence and whither. Accounting Organizations and Society, n. 28, p. 97-126, 2003.

BELKAOUI, Ahmed R. Accounting Theory. 4th ed., Thomson Learning: Business Press, 2000 .

BELL, Judith. Doing Your Research Project: a guide for first-time researchers in education and social science. 4th ed., Buckingham: Open University Press, 2005.

BHIMANI, A. European management accounting research: traditions in the making. European Accounting Review, v. 11, n. 1, p. 99-117, 2002.

BHIMANI, A.; GOSSELIN, M.; NCUBE, M.; OKANO, H. Activity-based costing: how far. Cost Management, v. 21, n. 3, p. 12-17, 2007.

BLAKE, J.; WRAITH, P. AMAT, O. Developing a new national management accounting framework - the Spanish case. European Business Review, v.12, n. 3, p. 122-128, 2000. 
BURNS, J.; SCAPENS, R. W. Conceptualizing management accounting change: an institutional framework. Management Accounting Research, n. 11, p. 3-25, 2000.

CAIADO, A.; AMARO, S. Aplicação de um modelo de custeio baseado em atividade (ABC) ao setor vitivinícola. Revista Contemporânea de Contabilidade, v. 3, n. 5, p. 11-40, 2006.

CHAMBERS, R. J. Positive Accounting Theory and the PA Cult. ABACUS, v. 29, n. 1, p. $1-26,1993$.

CHUA, W. F. Radical developments in accounting thought. Accounting Review, volume LXI, n. 4, p. 601-632, 1986.

CHUN, L. S.; KASSIM, N. H. A.; MINAI, B. Are management accounting systems in Malaysia outmoded? Singapore Management Review, v. 18, n. 1, p. 55-67, 1996.

CLARKE, P. J.; O'DEA, T. Management accounting systems: some field evidence from sixteen multi-national companies in Ireland. Irish Accounting Review, Spring, p. 199-216, 1994.

CLARKE, P. J.; HILL, N. T.; STEVENS, K. Activity-Based Costing in Ireland: Barriers to, and opportunities for, change. Critical Perspectives on Accounting, n. 10, p. 443-468, 1999.

COHEN, S.; VENIERIS, G.; KAIMENAKI, E. ABC: adopters, supporters, deniers and unawares. Managerial Auditing Journal, v. 20, n. 9, p. 981-1000, 2005.

COOPER, R. The Rise of Activity-Based Costing - Part Two: When Do I Need an ActivityBased Cost System? Journal of Cost Management, Fall, p. 41-48, 1988.

COTTON, B.; JACKMAN, S. Activity based costing: not a easy ABC. Chartered Accountants Journal of New Zealand, v. 81, n. 4, p. 35-37, 2002.

COVALESKI, M. A.; DIRSMITH, M. W. An Institutional Perspective on the Rise, Social Transformation, and Fall of a University Budget Category. Administrative Science Quarterly, n. 33, p. 562-587, 1988.

COVALESKI, M. A.; DIRSMITH, M. W. Managerial accounting research: the contributions of organizational and sociological theories. Journal of Management Accounting Research, n. 8, p. 1-35, 1996.

DEARMAN, D. T.; SHIELDS, M. D. Cost knowledge and cost-based judgment performance. Journal of Management Accounting Research, n.13, p. 1-18, 2001.

DRAKE, A.; HAKA, S. Does ABC information exacerbate hold-up problems in buyersupplier negotiations? The Accounting Review, v. 83, n. 1, p. 29-60, 2008.

DRURY, C.; TAYLES, M. Product costing in UK manufacturing organizations. European Accounting Review, v. 3, n. 3, p. 443-469, 1994.

ENGLUND, H.; GERDIN, J. Transferring knowledge across sub-genres of the ABC implementation literature. Management Accounting Research, n. 19, p. 149-162, 2008.

GHOSH, B. C.; CHAN, Y. Management accounting in Singapore - well in place? Managerial Auditing Journal, v. 12, n. 1, p. 16-18, 1997. 
HALDMA, T.; LÄÄTS, K. Contingencies influencing the management accounting practices of Estonian manufacturing companies. Management Accounting Research, n. 13, p. 379400, 2002.

HOPPER, T.; KOGA, T.; GOTO, J. Cost accounting in small and medium sized Japanese companies: an exploratory study. Accounting and Business Research, v. 30, n. 1, p. 73-86, 1999.

HOPPER, T.; MAJOR, M. Extending institutional analysis through theoretical triangulation: regulation and Activity Based Costing in Portuguese Telecommunications. European Accounting Review, v. 16, n. 1, p. 1-59, 2007.

HOOZÉE, S.; BRUGGEMAN, W. Identifying operational improvements during the design of a time-driven $\mathrm{ABC}$ system: the role of collective worker participation and leadership style. Management Accounting Research, n. 21, p. 185-198, 2010.

HUMPHREY, C.; SCAPENS, R. W. Methodological themes. Theories and case studies of organizational accounting practices: limitation or liberation? Accounting Auditing \& Accountability Journal, v. 9, n. 4, p. 86-106, 1996.

IAPMEI. Estrutura Empresarial Nacional. Lisboa: Gabinete de Estudos do Instituto de Apoio às Pequenas e Médias Empresas e ao Investimento, 2002.

IAPMEI. Sobre as PME's em Portugal. Lisboa: Direcção de Planeamento e Estudos do Instituto de Apoio às Pequenas e Médias Empresas e ao Investimento, 2008.

INNES, J.; MITCHELL, F. A survey of activity-based costing in the U.K.'s largest companies. Management Accounting Research, n. 6, p. 137-153, 1995.

INNES, J.; MITCHELL, F.; SINCLAIR, D. Activity-based costing in the U.K.'s largest companies: a comparison of 1994 and 1999 survey results. Management Accounting Research, n. 11, p. 349-362, 2000.

JOHNSON, H. Activity-Based Information: A Blueprint for World-class Management accounting. Management Accounting, June, p. 23-30, 1988.

JONES, T.; DUGDALE, D. The ABC bandwagon and the juggernaut of modernity. Accounting, Organizations and Society, n. 27, p. 121-163, 2002.

JOSHI, P. L. The international diffusion of new management accounting practices: The case of India. Journal of International Accounting Auditing \& Taxation, v. 10, n. 1, p. 85-109, 2001.

KALLUNKI, J.; SILVOLA, H. The effect of organizational life cycle stage on the use of activity based costing. Management Accounting Research, n. 19, p. 62-79, 2008.

KAPLAN, Robert S. The competitive advantage of management accounting. Journal of Management Accounting Research, n. 18, p. 127-135, 2006.

KENNEDY, T.; AFFLECK-GRAVES, J. The Impact of activity-Based Costing Techniques on Firm Performance. Journal of Management Accounting Research, n. 13, p. 19-45, 2001.

LUKKA, K.; GRANLUND, M. Cost accounting in Finland: current practice and trends of development. European Accounting Review, v. 5, n. 1, p. 1-28, 1996. 
MACARTHUR, J. Cultural influences on German versus U.S. management accounting practices. Management Accounting Quarterly, v. 7, n. 2, p. 10-16, 2006.

MACHADO, M. Métodos de repartição dos custos indiretos utilizados pelas PME's industriais portuguesas. Revista Contemporânea de Contabilidade, v. 1, n. 11, p.11-36, 2009.

MAIGA, A.; JACOBS F. F. Extent of ABC use and its consequences. Contemporary Accounting Research, v. 25, n. 2, p. 7-19, 2008.

MORGAN, G.; WILLMOTT, H. The New Accounting Research: On Making Accounting More Visible. Accounting Auditing \& Accountability Journal, v. 6, n. 4, p. 3-36, 1993.

NASSAR, M.; HUSAM, A.; SANGSTER, A. The diffusion of Activity-based costing: in Jordanian industrial companies. Qualitative Research in Accounting and Management, v. 8, n. 2, p. 180-200, 2011.

PIKE, R.; TAYLES, M.; MANSON, N. Activity-based costing user satisfaction and type of system: a research note. British Accounting Review, n. 43, p. 65-72, 2011.

QUEIROZ, A.; COSTA, R.; GOMES, S. O ABC em uma empresa de desenvolvimento de software: um estudo de caso. Revista Contemporânea de Contabilidade, v. 1, n. 1, p. 29-44, 2004.

RIVERO, Edilberto; EMBLEMSVAG, Jan. Activity-based life-cycle costing in long-range planning, Review of Accounting and Finance, v. 6, n. 4, p. 370-390, 2007.

SCAPENS, R. W. Researching Management Accounting Practice: The Role of Case Study Methods. British Accounting Review, n. 22, p. 259-281, 1990.

SCHOUTE, M. The relationship between product diversity, usage of advanced manufacturing technologies and activity-based costing adoption. British Accounting Review, n. 43, p. 120134, 2011.

SHIELDS, D. Management accounting practices in Europe: A view from the States. Management Accounting Research, n. 9, p. 501-513, 1998.

STOUT, D.; PROPRI, J. Implementing Time-Driven Activity-Based Costing at MediumSized Electronics Company. Management Accounting Quarterly, v. 12, n. 3, p. 1-11, 2011.

SWENSON, D. The Benefits of Activity-Based Cost Management to the Manufacturing Industry. Journal of Management Accounting Research, n. 7, p. 167-180, 1995.

YANG, Hui; YANG, Grant; WU, W. Employee demography moderate involvement of decision making and adoption of management accounting innovations for Chinese accountants. Journal of American Academy of Business, v. 9, n. 2, p. 338- 343, 2006.

YOUNG, S. M.; WIM, A.; CHEN, C. Assessing de quality of evidence in empirical management accounting research: the case of survey studies. Accounting, Organizations and Society, n. 30, p. 655-684, 2005.

WATTS, L.; ZIMMERMAN, J. L. Positive Accounting Theory: A Ten Year Perspective. Accounting Review, v. 65, n. 1, p. 131-156, 1990. 
ZIMMERMAN, J. L. Conjectures Regarding Empirical Managerial Accounting Research. Journal of Accounting and Economics, n. 32, p. 411-427, 2001. 
Activity Based Costing knowledge: empirical study on small and medium-size enterprises

\section{Annex - Interviews}

\begin{tabular}{|c|c|c|c|c|c|}
\hline $\mathrm{N}^{\mathrm{o}}$ & DATE & ENTERPRISE & DISTRICT & & ACTIVITY \\
\hline 1 & $18 / 7 / 05$ & $\begin{array}{l}\text { CONCRETOPE - Fábrica de Betão } \\
\text { Pronto, S.A. }\end{array}$ & Setúbal & 26610 & Manufacture of Concrete \\
\hline 2 & $20 / 7 / 05$ & $\begin{array}{lll}\text { CRIAMÁRMORE } & - & \text { Mármores } \\
\text { Portugueses, lda. } & & \\
\end{array}$ & Évora & 26701 & Marble Processing \\
\hline 3 & $10 / 10 / 05$ & $\begin{array}{l}\text { SOCIMBAL - Sociedade Industrial } \\
\text { de Alimentos, lda. }\end{array}$ & Setúbal & 15201 & Manufacture of frozen foods \\
\hline 4 & $13 / 10 / 05$ & $\begin{array}{l}\text { PORAMA - Industria de Madeiras, } \\
\text { S.A. }\end{array}$ & Lisboa & 20302 & Wood Industry \\
\hline 5 & $18 / 10 / 05$ & GUIDE - Artes gráficas, lda. & Lisboa & 22220 & Print \\
\hline 6 & $18 / 10 / 05$ & $\begin{array}{lll}\text { RIETER - } & \text { Componentes } & \text { para } \\
\text { Veículos, lda. } & & \\
\end{array}$ & Setúbal & 34300 & Car components production \\
\hline 7 & $18 / 10 / 05$ & $\begin{array}{l}\text { CSP - Componentes Semicondutores } \\
\text { de Portugal, lda. }\end{array}$ & Setúbal & 32100 & $\begin{array}{l}\begin{array}{l}\text { Manufacture of electronic } \\
\text { components }\end{array} \\
\end{array}$ \\
\hline 8 & $25 / 10 / 05$ & $\begin{array}{l}\text { OLEGÁRIO FERNANDES - Artes } \\
\text { gráficas, S.A. }\end{array}$ & Lisboa & 22220 & Print \\
\hline 9 & $25 / 10 / 05$ & Covêlo e Pinto, lda. & Setúbal & 20101 & Wood Industry \\
\hline 10 & $29 / 10 / 05$ & Rodrigues e Almeida, Lda. & Faro & 28401 & Metal works \\
\hline 11 & $8 / 11 / 05$ & Filipe e Henriques, S.A. & Leiria & 36141 & Manufacture of furniture \\
\hline 12 & $8 / 11 / 05$ & $\begin{array}{l}\text { SOFIMA }- \text { Sociedade fundição } \\
\text { Injectada da Maceira, Lda. }\end{array}$ & Leiria & 27540 & Metallurgy - Foundry \\
\hline 13 & $14 / 11 / 05$ & Ferreira \& Varela, Lda. & Santarém & 26610 & Manufacture of Concrete \\
\hline 14 & $14 / 11 / 05$ & $\begin{array}{l}\text { FORMATO - formulários Múltiplos } \\
\text { Comerciais, S.A. }\end{array}$ & Leiria & 22220 & Print \\
\hline 15 & $22 / 11 / 05$ & PRISMET - Quadros Eléctricos, S.A. & Setúbal & 31620 & $\begin{array}{l}\begin{array}{l}\text { Manufacture of electrical } \\
\text { equipment }\end{array} \\
\end{array}$ \\
\hline 16 & $22 / 11 / 05$ & $\begin{array}{l}\text { SOCTIP - Sociedade Tipográfica, } \\
\text { S.A. }\end{array}$ & Santarém & 22220 & Print \\
\hline 17 & $5 / 12 / 05$ & $\begin{array}{l}\text { Cerâmica Torreense de } \\
\text { Pereira, Sucessores, Lda. }\end{array}$ & Lisboa & 26401 & Brickworks \\
\hline 18 & $6 / 12 / 05$ & $\begin{array}{l}\text { TOMIX - Indústria de Equipamentos } \\
\text { Agrícolas Industriais,Lda. }\end{array}$ & Lisboa & 29320 & $\begin{array}{l}\text { Manufacture of agricultural } \\
\text { equipment }\end{array}$ \\
\hline 19 & $6 / 12 / 05$ & $\begin{array}{l}\text { JOPER - Indústria de Equipamentos } \\
\text { Agrícolas, Lda. }\end{array}$ & Lisboa & 29320 & $\begin{array}{l}\text { Manufacture of agricultural } \\
\text { equipment }\end{array}$ \\
\hline 20 & $6 / 12 / 05$ & Cerâmica do Outeiro do Seixo, S.A. & Lisboa & 26401 & Brickworks \\
\hline 21 & $6 / 12 / 05$ & Cerâmica Rosário, S.A. & Leiria & 26401 & Brickworks \\
\hline 22 & $31 / 1 / 06$ & Joaquim Duarte Urmal \& Filhos, Lda. & Lisboa & 26701 & Transformation marble \\
\hline 23 & $13 / 3 / 06$ & $\begin{array}{l}\text { COPAM - Companhia Portuguesa de } \\
\text { Amidos, S.A. }\end{array}$ & Lisboa & 15620 & Manufacture of starches \\
\hline 24 & $13 / 3 / 06$ & Manuel Peres Júnior \& Filhos, S.A. & Lisboa & 22220 & Print \\
\hline 25 & $20 / 3 / 06$ & Texto Editores, lda. & Lisboa & 22110 & Publishing and printing \\
\hline 26 & $21 / 3 / 06$ & $\begin{array}{l}\text { Martelha - Cerâmica de Martingança, } \\
\text { lda. }\end{array}$ & Leiria & 26401 & Brickworks \\
\hline 27 & $21 / 3 / 06$ & $\begin{array}{l}\text { Plastimar - Indústria de Plásticos } \\
\text { Penichenses, lda. }\end{array}$ & Leiria & 25220 & Manufacture of plastic \\
\hline 28 & $21 / 3 / 06$ & Produtos Alimentares Peipen, lda. & Leiria & 15201 & Manufacture of frozen foods \\
\hline 29 & $27 / 3 / 06$ & Leiriviga - Pré-esforçados, lda. & Leiria & 26610 & Manufacture of Concrete \\
\hline 30 & $27 / 3 / 06$ & J. Coelho da Silva, lda. & Leiria & 26401 & Brickworks \\
\hline 31 & $27 / 3 / 06$ & $\begin{array}{l}\text { Compogal - Indústria de Polímeros, } \\
\text { S.A. }\end{array}$ & Leiria & 24160 & $\begin{array}{l}\text { Manufacture of chemicals - } \\
\text { PVC granules }\end{array}$ \\
\hline 32 & $11 / 4 / 06$ & $\begin{array}{l}\text { Durit - Metalúrgica Portuguesa do } \\
\text { Tungsténio, lda. }\end{array}$ & Aveiro & 28622 & $\begin{array}{l}\text { Fabricated metal products - } \\
\text { tools and parts }\end{array}$ \\
\hline 33 & $11 / 4 / 06$ & Henrique Vieira \& Filhos, lda. & Aveiro & 29320 & $\begin{array}{l}\text { Manufacture of agricultural } \\
\text { equipment }\end{array}$ \\
\hline 34 & $12 / 4 / 06$ & $\begin{array}{l}\text { Guialmi }- \text { Empresa de Móveis } \\
\text { Metálicos, S.A. }\end{array}$ & Aveiro & 36141 & Manufacture of furniture \\
\hline 35 & $12 / 4 / 06$ & Utilizas - Exportador de Artigos de & Aveiro & 28752 & Fabricated metal products - \\
\hline
\end{tabular}




\begin{tabular}{|c|c|c|c|c|c|}
\hline & & Jardim e Lar, S.A. & & & Bathroom accessories \\
\hline 36 & $12 / 4 / 06$ & $\begin{array}{l}\text { Indelague - Indústria Eléctrica de } \\
\text { Águeda, S.A. }\end{array}$ & Aveiro & 31620 & $\begin{array}{l}\text { Manufacture of electrical } \\
\text { equipment }\end{array}$ \\
\hline 37 & $12 / 4 / 06$ & Ramalhos, S.A. & Aveiro & 29530 & $\begin{array}{l}\text { Manufacture of machinery for } \\
\text { industry }\end{array}$ \\
\hline 38 & $24 / 5 / 06$ & $\begin{array}{l}\text { DOMINÓ - Indústrias Cerâmicas, } \\
\text { S.A. }\end{array}$ & Coimbra & 26302 & $\begin{array}{l}\text { Manufacture of tiles and } \\
\text { mosaics }\end{array}$ \\
\hline 39 & $24 / 5 / 06$ & $\begin{array}{l}\text { IBEROBRITA }- \text { Produtora } \mathrm{de} \\
\text { Inertes, S.A. }\end{array}$ & Leiria & 14210 & Production aggregates (crushed) \\
\hline 40 & $29 / 5 / 06$ & Coimbra Editora, Lda. & Coimbra & 22110 & Publishing and printing \\
\hline 41 & $2 / 6 / 06$ & $\begin{array}{l}\text { BORVUL - Borrachas Vulcanizadas, } \\
\text { Lda. }\end{array}$ & Leiria & 25130 & Manufacture of rubber \\
\hline 42 & $2 / 6 / 06$ & $\begin{array}{l}\text { EMPOBOR - Empresa Portuguesa de } \\
\text { Borrachas, Lda. }\end{array}$ & Leiria & 25130 & Manufacture of rubber \\
\hline 43 & $8 / 6 / 06$ & $\begin{array}{l}\text { PAVICER - Pavimentos cerâmicos, } \\
\text { Lda. }\end{array}$ & Coimbra & 26610 & Manufacture of Concrete \\
\hline 44 & $4 / 7 / 06$ & $\begin{array}{l}\text { ARTEBEL - Artefactos de Betão, } \\
\text { S.A. }\end{array}$ & Leiria & 26610 & Manufacture of Concrete \\
\hline 45 & $4 / 7 / 06$ & $\begin{array}{l}\text { MARCOVIL - Metalomecânica de } \\
\text { Viseu, S.A. }\end{array}$ & Viseu & 29243 & $\begin{array}{l}\text { Manufacture of machinery and } \\
\text { equipment }\end{array}$ \\
\hline 46 & $4 / 7 / 06$ & $\begin{array}{l}\text { FERMA - Fernando Martins de } \\
\text { Carvalho \& Irmãos, S.A. }\end{array}$ & Viseu & 28120 & $\begin{array}{l}\text { Manufacture of doors and } \\
\text { windows of metal }\end{array}$ \\
\hline 47 & $12 / 7 / 06$ & $\begin{array}{l}\text { PORTAX - Componentes de Móveis, } \\
\text { S.A. }\end{array}$ & Viseu & 36141 & Manufacture of furniture \\
\hline 48 & $12 / 7 / 06$ & $\begin{array}{lrr}\text { IBEROPERFIL } & - & \text { Perfis } \\
\text { Postetransformados, S.A. } & \\
\end{array}$ & Viseu & 36141 & Manufacture of furniture \\
\hline 49 & $12 / 7 / 06$ & $\begin{array}{l}\text { CONVESTE - Artigos de Vestuário, } \\
\text { S.A. }\end{array}$ & Porto & 18222 & Making clothing \\
\hline 50 & $18 / 7 / 06$ & $\begin{array}{l}\text { SOIMA - Sociedade Industrial de } \\
\text { Máquinas, S.A. }\end{array}$ & Viseu & 29520 & $\begin{array}{l}\text { Manufacture of machinery for } \\
\text { industry }\end{array}$ \\
\hline 51 & $18 / 7 / 06$ & $\begin{array}{l}\text { LABESFAL - Laboratórios Almiro, } \\
\text { S.A. }\end{array}$ & Viseu & 24421 & Manufacture of medicines \\
\hline 52 & $18 / 7 / 06$ & $\begin{array}{l}\text { A. DIAS RAMOS - Máquinas e } \\
\text { Ferramentas, LDA. }\end{array}$ & Porto & 29401 & $\begin{array}{l}\text { Manufacture of machinery for } \\
\text { metal working }\end{array}$ \\
\hline 53 & $18 / 7 / 06$ & $\begin{array}{l}\text { OXISOL }- \text { Construção } \text { Soldada, } \\
\text { LDA. }\end{array}$ & Porto & 28110 & Manufacture of metal structures \\
\hline 54 & $19 / 7 / 06$ & $\begin{array}{l}\text { FREZITE - Ferramentas de Corte, } \\
\text { S.A. }\end{array}$ & Porto & 28622 & $\begin{array}{l}\text { Fabricated metal products - } \\
\text { tools and parts }\end{array}$ \\
\hline 55 & $19 / 7 / 06$ & $\begin{array}{l}\text { CELOPLÁS - Plásticos para a } \\
\text { Industria, S.A. }\end{array}$ & Braga & 25220 & Manufacture of plastic \\
\hline 56 & $19 / 7 / 06$ & B. Sousa Dias \& Filhos, S.A. & Braga & 17210 & Weaving cotton \\
\hline 57 & $19 / 7 / 06$ & A Cimenteira do Louro, lda. & Braga & 26610 & Manufacture of Concrete \\
\hline 58 & $31 / 7 / 06$ & Gouveia \& Campos, lda. & Viseu & 18222 & Making clothing \\
\hline
\end{tabular}

